Penggunaan Materi Teori....(Ramtia Darma Putri)

\title{
PENGGUNAAN MATERI TEORI KARIER JOHN HOLLAND \\ TERHADAP PENINGKATAN PERENCANAAN KARIER SISWA MELALUI LAYANAN INFORMASI BERMUATAN PEMBELAJARAN KONTEKSTUAL
}

\author{
Oleh: Ramtia Darma Putri ${ }^{1}$ Syska Purnamasari ${ }^{2}$ \\ (Dosen Universitas PGI Palembang) \\ tyadhuarrma27@gmail.com, syskapurnamasari@gmail.com
}

\begin{abstract}
Abstrak
Penelitian ini bertujuan untuk mengetahui perbedaan yang signifikan pada perencanaan karier siswa sebelum dan sesudah diberi layanan informasi bermuatan pembelajaran kontekstual dengan materi karier John Holland. Penelitian ini merupakan penelitian kuantitatif dengan metode penelitian eksperimen yang menggunakan desain Quasi Experimental. Bentuk Quasi Experimental yang digunakan dalam penelitian ini adalah Pretest Posttest One Group Design. Subjek dalam penelitian ini adalah siswa SMA PGRI 2 Palembang kelas X IPS 3. Instrumen penelitian yang digunakan adalah Instrumen Perencanaan Karier Siswa dengan model Skala Likert dengan nilai validitas 1 dan reliabilitas 0.866. Data yang diperoleh selanjutnya dianalisis dan diuji dengan teknik Paired Samples t-test dengan bantuan SPSS versi 17.00. Temuan dalam penelitian ini mengungkapkan terdapat perbedaan yang signifikan pada perencanaan karier siswa sebelum dan sesudah diberi layanan informasi informasi bermuatan pembelajaran kontekstual dengan materi karier John Holland. Hasil penelitian diharapkan dapat berkontribusi bagi personil sekolah maupun lingkungan dalam meningkatkan perencanaan karier siswa di sekolah.
\end{abstract}

Kata Kunci : Teori Karier John Holland, Perencanaan Karier, Layanan Informasi dan Pembelajaran Kontekstual

\section{THE USE OF JOHN HOLLAND'S CAREER THEORY MATTERS ON IMPROVING STUDENT CAREER PLANNING THROUGH TRENGTHENING INFORMATION SERVICES CONTEXTUAL LEARNING}

\begin{abstract}
This study aims to find out the significant differences in student career planning before and after being given information services containing contextual learning with John Holland career material. This research is a quantitative research with experimental research method that uses Quasi Experimental design. The Quasi Experimental form used in this study is the Pretest Posttest One Group Design. Subjects in this study were students of SMA PGRI 2 Palembang class $X$
\end{abstract}


IPS 3. The research instrument used was the Student Career Planning Instrument with a Likert Scale model with validity value 1 and 0.866 reliability. The data obtained were then analyzed and tested with Paired Samples t-test technique with the help of SPSS version 17.00. The findings in this study revealed that there were significant differences in student career planning before and after being given information information services containing contextual teaching and learning with John Holland career material. The results of the study are expected to contribute to school personnel and the environment in improving student career planning at school.

Keywords: John Holland Career Theory, Career Planning, Information Services and Contextual Teaching and Learning

\section{A. PENDAHULUAN}

Data BPS Sumatera Selatan menjelaskan penganguran di Sumatera Selatan (Sumsel) tahun 2015 mengalami kenaikan mencapai 5.03\% dibandingkan akhir tahun 2014 sebesar 4.96\%. Pengangguran yang timbul akibat minimnya lapangan kerja di daerah Sumsel turut menjadi salah satu faktor penyumbang munculnya tindakan kriminalitas di kota Palembang. Februari 2015 kasus narkoba paling banyak dengan jumlah 501 tahanan, koruptor 75 orang, dan sisanya sebanyak 667 tahanan, dari kejahatan umum lainnya (Nesidatu, 2015). Kasus seperti ini sudah seharusnya menjadi acuan bagi guru bimbingan dan konseling (selanjutnya disebut BK) untuk dapat turut serta dalam upaya mengurangi pengangguran dengan cara memberikan pelayanan BK dalam bidang karier.

Melalui pelayanan BK dalam bidang karier, guru BK dapat menggiring siswa untuk menemukan kariernya berdasarkan minat yang dimilikinya. Yusuf (2002:35) mengungkapkan bahwa seseorang yang memasuki pekerjaan berdasarkan dengan keadaan dirinya mencakup kemampuan, kecerdasan, minat, bakat, sikap, nilai-nilai, dan sifat-sifat pribadi lainnya, akan melakukan pekerjaan dengan baik karena sesuai dengan kemampuan minat, bakat, dan nilai-nilai yang dianutnya. Pekerjaan itu memberikan kepuasan bagi dirinya, dan mendorong yang bersangkutan untuk berbuat lebih baik dan produktif. 
Penggunaan Materi Teori....(Ramtia Darma Putri)

Hal tersebut sejalan dengan teori karier yang diungkapkan oleh salah satu ahli karier, yaitu John L. Holland. Holland percaya bahwa pemilihan pekerjaan seseorang tidak terlepas dari kepribadiannya. Seseorang menyatakan dirinya, minat dan nilai-nilai hidupnya melalui pilihan pekerjaan.

Berdasarkan hal di atas, sudah selayaknya guru BK membantu mempersiapkan perencanaan karier bagi siswa. karena dapat dijadikan pedoman siswa dalam pengambilan keputusan mengenai kariernya di masa depan. Perencanaan karier perlu dipersiapkan dan ditingkatkan karena tidak semua siswa memiliki perencanaan karier yang matang.

Fenomena yang terjadi saat ini adalah adanya proses pembelajaran yang dipusatkan pada siswa, sehingga membuat guru harus memiliki keterampilan yang baik dalam mengelola kelas. Pemusatan proses pembelajaran pada siswa menjadikan guru bukan lagi satu-satunya sumber belajar bagi siswa. Hal ini berdampak pada bagaimana cara guru untuk mampu mengelola kelas, menjadi wadah bagi siswa untuk bertanya, dan juga sekaligus dapat mengaktifkan siswa. Kegiatan seperti ini juga berlaku bagi guru BK. Dengan adanya jam tatap muka di dalam kelas, guru BK harus mampu menciptakan iklim yang kondusif dalam rangka memberikan pelayanan terbaik bagi siswa asuhnya. Salah satu hal yang dapat diberikan guru BK adalah dengan menerapkan pembelajaran kontekstual pada salah satu layanan yang diberikan.

Depdiknas (dalam Taniredja, Faridli, \& Harmianti, 2013:49) menyatakan pembelajaran kontekstual adalah konsep belajar yang membantu guru dalam mengaitkan antara materi yang diajarkannya dengan situasi dunia nyata siswa. Situasi dunia nyata menjadi begitu penting untuk diberikan kepada siswa, karena dalam pemberian layanan BK, segala sesuatu hal harus tersentuh pada ranah bidang bimbingan pribadi, sosial, belajar, dan karier. Tak terlebih pada bidang bimbingan karier.

Penelitian ini adalah tindak lanjut atas penelitian yang telah dilakukan lebih dahulu mengenai efektivitas layanan informasi dengan pendekatan kontekstual 
dalam meningkatkan arah perencanaan karier siswa SMK, namun dalam penelitian ini lebih memfokuskan pada pengaruh teori John Holland dan subjek penelitian menitikberatkan pada siswa SMA.

Berdasarkan uraian singkat di atas, maka peneliti tertarik untuk mengadakan penelitian tentang pengaruh pembelajaran kontekstual melalui layanan informasi dengan materi tipe kepribadian John Holland terhadap peningkatan perencanaan karier siswa.

\section{B. METODOLOGI PENELITIAN}

Penelitian ini merupakan penelitian kuantitatif dengan metode penelitian eksperimen menggunakan desain Quasi Experimental. Bentuk Quasi Experimental yang digunakan dalam penelitian ini adalah Pretest Posttest One Group Design. Subjek dalam penelitian ini adalah siswa SMA PGRI 2 Palembang yang berjumlah 33 orang. Instrumen yang digunakan dalam penelitian ini menggunakan model skala Likert. Instrumen perencanaan karier siswa menunjukkan tingkat validitas instrumen sebesar 1 dan reliabilitas dengan nilai Alpha Cronbach sebesar 0.866. Data yang telah terkumpul, dianalisis dengan cara menghitung skor rata-rata perencanaan karier siswa yang kemudian dideskripsikan menggunakan norma pengkategorian sebagai berikut.

Tabel 1. Kategorisasi Perencanaan Karier Siswa

\begin{tabular}{|c|c|c|}
\hline Skor & Persentase (\%) & Kategori \\
\hline$\geq 105$ & 84 & Sangat Tinggi \\
\hline $84-104$ & $67.5-83.2$ & Tinggi \\
\hline $63-83$ & $50.4-66.4$ & Sedang \\
\hline $43-62$ & $34.4-49.6$ & Rendah \\
\hline$\leq 42$ & 33.6 & Sangat Rendah \\
\hline
\end{tabular}

Data yang diperoleh selanjutnya dianalisis dan diuji dengan teknik Paired Samples t-test. 
Penggunaan Materi Teori....(Ramtia Darma Putri)

\section{HASIL PENELITIAN}

\section{HASIL PRETEST}

Tujuan dilakukannya pretest dalam penelitian ini adalah untuk mengetahui gambaran tingkat perencanaan karier siswa sebelum diberikan perlakuan. Berikut disajikan kondisi pretest arah perencanaan karier siswa.

Tabel 2. Skor Pretest Perencanaan Karier Siswa

\begin{tabular}{|c|c|c|c|c|c|}
\hline Kode Siswa & Skor & Kategori & Kode Siswa & Skor & Kategori \\
\hline K 1 & 71 & Sedang & K 17 & 86 & Tinggi \\
\hline K 2 & 79 & Sedang & K 18 & 75 & Sedang \\
\hline K 3 & 75 & Sedang & K 19 & 85 & Tinggi \\
\hline K 4 & 77 & Sedang & K 20 & 89 & Tnggi \\
\hline K 5 & 75 & Sedang & K 21 & 73 & Sedang \\
\hline K 6 & 67 & Sedang & K 22 & 79 & Sedang \\
\hline K 7 & 64 & Sedang & K 23 & 81 & Sedang \\
\hline K 8 & 71 & Sedang & K 24 & 80 & Sedang \\
\hline K 9 & 71 & Sedang & K 25 & 58 & Rendah \\
\hline K 10 & 75 & Sedang & K 26 & 79 & Sedang \\
\hline K 11 & 70 & Sedang & K 27 & 78 & Sedang \\
\hline K 12 & 62 & Rendah & K 28 & 82 & Sedang \\
\hline K 13 & 73 & Sedang & K 29 & 77 & Sedang \\
\hline K 14 & 69 & Sedang & K 30 & 75 & Sedang \\
\hline K 15 & 77 & Sedang & K 31 & 79 & Sedang \\
\hline K 16 & 76 & Sedang & K 32 & 77 & Sedang \\
\hline \multicolumn{2}{|r|}{} & \multicolumn{2}{|l}{75.5} & 87 & Tinggi \\
\hline & & & & & S 33 edang \\
\hline
\end{tabular}

Berdasarkan tabel di atas, tergambar perencanaan karier siswa sebelum diberikan perlakuan. Gambaran perencanaan karier siswa yang berada pada kategori rendah berjumlah 2 orang, kategori sedang berjumlah 27 orang, dan kategori tinggi berjumlah 4 orang. Hasil rata-rata skor pretest perencanaan karier siswa adalah sebesar 75.5 yang berada pada kategori sedang. Data hasil pretest dapat dilihat pada tabel di bawah ini.

Tabel 3. Distribusi Frekuensi Perencanaan Karier Siswa (pretest)

\begin{tabular}{|c|c|c|c|c|}
\hline \multirow{2}{*}{ Interval } & \multirow{2}{*}{ Kategori } & Frekuensi & \multirow{2}{*}{$\mathbf{N}$} & \multirow{2}{*}{$\%$} \\
\cline { 3 - 4 } & Kelompok & & \\
\hline$\geq 105$ & Sangat Tinggi & 0 & 0 & 0 \\
\hline $84-104$ & Tinggi & 4 & 4 & 12,12 \\
\hline $63-83$ & Sedang & 27 & 27 & 81.8 \\
\hline
\end{tabular}


Wahana Didaktika Vol. 16 No.2 Mei 2018 : 243-255

\begin{tabular}{|c|c|c|c|c|}
\hline \multirow{2}{*}{ Interval } & \multirow{2}{*}{ Kategori } & Frekuensi & \multirow{2}{*}{ N } & \multirow{2}{*}{$\%$} \\
\cline { 3 - 3 } & Kelompok & & \\
\hline $43-62$ & Rendah & 2 & 2 & 6.06 \\
\hline$\leq 42$ & Sangat Rendah & 0 & 0 & 0 \\
\hline \multicolumn{2}{|c|}{ Jumlah } & 33 & 33 & 100 \\
\hline
\end{tabular}

\section{HASIL POSTTEST}

Tujuan dilakukannya posttest dalam penelitian ini adalah untuk mengetahui gambaran tingkat perencanaan karier siswa sesudah diberikan perlakuan. Berikut disajikan kondisi posttest arah perencanaan karier siswa.

\section{Tabel 4. Skor Posttest Perencanaan Karier Siswa}

\begin{tabular}{|c|c|c|c|c|c|}
\hline Kode Siswa & Skor & Kategori & Kode Siswa & Skor & Kategori \\
\hline K 1 & 91 & Tinggi & K 17 & 107 & Tinggi \\
\hline K 2 & 100 & Tinggi & K 18 & 104 & Tinggi \\
\hline K 3 & 97 & Tinggi & K 19 & 100 & Tinggi \\
\hline K 4 & 100 & Tinggi & K 20 & 104 & Tinggi \\
\hline K 5 & 98 & Tinggi & K 21 & 100 & Tinggi \\
\hline K 6 & 113 & Sangat Tinggi & K 22 & 103 & Tinggi \\
\hline K 7 & 99 & Tinggi & K 23 & 105 & Sangat Tinggi \\
\hline K 8 & 99 & Tinggi & K 24 & 114 & Sangat Tinggi \\
\hline K 9 & 101 & Tinggi & K 25 & 109 & Sangat Tinggi \\
\hline K 10 & 103 & Tinggi & K 26 & 102 & Tinggi \\
\hline K 11 & 116 & Sangat Tinggi & K 27 & 102 & Tinggi \\
\hline K 12 & 102 & Tinggi & K 28 & 91 & Tinggi \\
\hline K 13 & 105 & Sangat Tinggi & K 29 & 107 & Sangat Tinggi \\
\hline K 14 & 106 & Sangat Tinggi & K 30 & 100 & Tinggi \\
\hline K 15 & 109 & Sangat Tinggi & K 31 & 103 & Tinggi \\
\hline K 16 & 103 & Tinggi & K 32 & 97 & Tinggi \\
\hline \multicolumn{7}{|r|}{103} & K 33 & 106 & Sangat Tinggi \\
\hline Rata-rata & & & & Tinggi \\
\hline
\end{tabular}

Berdasarkan tabel di atas, maka perencanaan karier siswa yang berada pada kategori tinggi berjumlah 23 orang dan yang berada pada kategori sangat tinggi berjumlah 10 orang. Hasil rata-rata skor posttest perencanaan karier siswa adalah sebesar 103 yang berada pada kategori tinggi. Data hasil posttest dapat dilihat pada tabel di bawah ini.

Tabel 5. Distribusi Frekuensi Perencanaan Karier Siswa (Posttest) 
Penggunaan Materi Teori....(Ramtia Darma Putri)

\begin{tabular}{|c|c|c|c|c|}
\hline \multirow{2}{*}{ Interval } & \multirow{2}{*}{ Kategori } & Frekuensi & \multirow{2}{*}{ N } & \multirow{2}{*}{} \\
\cline { 2 - 3 } & Kelompok & & \\
\hline$\geq 105$ & Sangat Tinggi & 10 & 10 & 30.3 \\
\hline $84-104$ & Tinggi & 23 & 23 & 69.7 \\
\hline $63-83$ & Sedang & 0 & 0 & 0 \\
\hline $43-62$ & Rendah & 0 & 0 & 0 \\
\hline$\leq 42$ & Sangat Rendah & 0 & 0 & 0 \\
\hline \multicolumn{2}{|c|}{ Jumlah } & 33 & 33 & 100 \\
\hline
\end{tabular}

\section{HASIL PRETEST DAN POSTTEST PERENCANAAN KARIER SISWA}

Data penelitian diperoleh berdasarkan instrument yang telah diberikan kepada 33 orang siswa sebelum perlakuan (pretest) dan sesudah perlakuan (posttest). Berikut disajikan skor masing-masing perencanaan karier siswa sebelum dan sesudah diberikan perlakuan.

Tabel 6. Perbandingan Perencanaan Karier Siswa Pretest-posttest

\begin{tabular}{|c|c|c|c|c|c|}
\hline \multirow{2}{*}{ No } & \multirow{2}{*}{ Kode siswa } & \multicolumn{2}{|c|}{ Pretest } & \multicolumn{2}{c|}{ Posttest } \\
\cline { 3 - 6 } & & Skor & Kategori & Skor & Kategori \\
\hline 1 & K 1 & 71 & Sedang & 91 & Tinggi \\
\hline 2 & K 2 & 79 & Sedang & 100 & Tinggi \\
\hline 3 & K 3 & 75 & Sedang & 97 & Tinggi \\
\hline 4 & K 4 & 77 & Sedang & 100 & Tinggi \\
\hline 5 & K 5 & 75 & Sedang & 98 & Tinggi \\
\hline 6 & K 6 & 67 & Sedang & 113 & Sangat Tinggi \\
\hline 7 & K 7 & 64 & Sedang & 99 & Tinggi \\
\hline 8 & K 8 & 71 & Sedang & 99 & Tinggi \\
\hline 9 & K 9 & 71 & Sedang & 101 & Tinggi \\
\hline 10 & K 10 & 75 & Sedang & 103 & Tinggi \\
\hline 11 & K 11 & 70 & Sedang & 116 & Sangat Tinggi \\
\hline 12 & K 12 & 62 & Rendah & 102 & Tinggi \\
\hline 13 & K 13 & 73 & Sedang & 105 & Sangat Tinggi \\
\hline 14 & K 14 & 69 & Sedang & 106 & Sangat Tinggi \\
\hline 15 & K 15 & 77 & Sedang & 109 & Sangat Tinggi \\
\hline 16 & K 16 & 76 & Sedang & 103 & Tinggi \\
\hline 17 & K 17 & 86 & Tinggi & 107 & Tinggi \\
\hline 18 & K 18 & 75 & Sedang & 104 & Tinggi \\
\hline 19 & K 19 & 85 & Tinggi & 100 & Tinggi \\
\hline 20 & K 20 & 89 & Tnggi & 104 & Tinggi \\
\hline 21 & K 21 & 73 & Sedang & 100 & Tinggi \\
\hline 22 & K 22 & 79 & Sedang & 103 & Tinggi \\
\hline 23 & K 23 & 81 & Sedang & 105 & Sangat Tinggi \\
\hline 24 & K 24 & 80 & Sedang & 114 & Sangat Tinggi \\
\hline 25 & K 25 & 58 & Rendah & 109 & Sangat Tinggi \\
\hline
\end{tabular}


Wahana Didaktika Vol. 16 No.2 Mei 2018 : 243-255

\begin{tabular}{|c|c|c|c|c|c|}
\hline \multirow{2}{*}{ No } & \multirow{2}{*}{ Kode siswa } & \multicolumn{2}{|c|}{ Pretest } & \multicolumn{2}{|c|}{ Posttest } \\
\hline & & Skor & Kategori & Skor & Kategori \\
\hline 26 & K 26 & 79 & Sedang & 102 & Tinggi \\
\hline 27 & K 27 & 78 & Sedang & 102 & Tinggi \\
\hline 28 & K 28 & 82 & Sedang & 91 & Tinggi \\
\hline 29 & K 29 & 77 & Sedang & 107 & Sangat Tinggi \\
\hline 30 & K 30 & 75 & Sedang & 100 & Tinggi \\
\hline 31 & K 31 & 79 & Sedang & 103 & Tinggi \\
\hline 32 & K 32 & 77 & Sedang & 97 & Tinggi \\
\hline 33 & K 33 & 87 & Tinggi & 106 & Sangat Tinggi \\
\hline & Rata-rata & 75.5 & Sedang & 103 & Tinggi \\
\hline
\end{tabular}

Berdasarkan Tabel 6 terlihat bahwa perencanaan karier siswa mengalami perubahan atau peningkatan setelah diberikan layanan informasi bermuatan pembelajaran kontekstual dengan materi karier John Holland. Sebelum diberikan perlakuan, rata-rata skor pretest sebesar 75.5 dan berada pada kategori sedang. Selanjutnya, setelah diberikan perlakuan, rata-rata skor posttest meningkat menjadi sebesar 103 dan berada pada kategori tinggi.

Perbedaan frekuensi kondisi kelompok eksperimen dari hasil pretest dan posttest tentang perencanaan karier siswa dapat dilihat pada tabel berikut ini.

Tabel 7. Hasil Pretest dan Posttest Perencanaan Karier Siswa

\begin{tabular}{|c|c|c|c|c|c|}
\hline \multirow{2}{*}{ Interval } & \multirow{2}{*}{ Kategori } & \multicolumn{2}{|c|}{ Pretest } & \multicolumn{2}{c|}{ Posttest } \\
\cline { 2 - 5 } & & Frekuensi & $\%$ & Frekuensi & $\%$ \\
\hline$\geq 105$ & Sangat Tinggi & 0 & 0 & 10 & 30.3 \\
\hline $84-104$ & Tinggi & 4 & 12,12 & 23 & 69.7 \\
\hline $63-83$ & Sedang & 27 & 81.8 & 0 & 0 \\
\hline $43-62$ & Rendah & 2 & 6.06 & 0 & 0 \\
\hline$\leq 42$ & Sangat Rendah & 0 & 0 & 0 & 0 \\
\hline \multicolumn{2}{|c|}{ Jumlah } & 33 & 100 & 33 & 100 \\
\hline
\end{tabular}

Berdasarkan Tabel 7 dapat diketahui bahwa terdapat perbedaan perencanaan karier siswa sebelum dan sesudah mendapat perlakuan layanan informasi bermuatan pembelajaran kontekstual dengan materi karier John Holland. Pada saat pretest, perencanaan karier 2 orang siswa berada pada kategori rendah dengan persentase sebesar 6.06\%, perencanaan karier 27 orang siswa berada pada kategori sedang dengan persentase sebesar $81.8 \%$, dan 4 orang siswa berada pada kategori tinggi dengan persentase sebesar $12.12 \%$. Setelah diberikan perlakuan 
Penggunaan Materi Teori....(Ramtia Darma Putri)

terjadi perubahan dimana dapat dilihat dari hasil posttest, sebanyak 23 orang siswa berada dalam kategori tinggi dengan persentase sebesar 69.7\%, dan 10 orang siswa berada dalam kategori sangat tinggi dengan persentase sebesar $30.3 \%$.

Berdasarkan Tabel 7, terlihat 33 orang anggota kelompok eksperimen yang dilibatkan dalam perhitungan, mengalami peningkatan skor dari pretest dan posttest atau mengalami perubahan setelah diberikan layanan informasi bermuatan pembelajaran kontekstual dengan materi karier John Holland. Untuk melihat kondisi masing-masing perencanaan karier siswa dari kelompok pretest dan posttest dapat dijelaskan pada gambar di bawah ini.

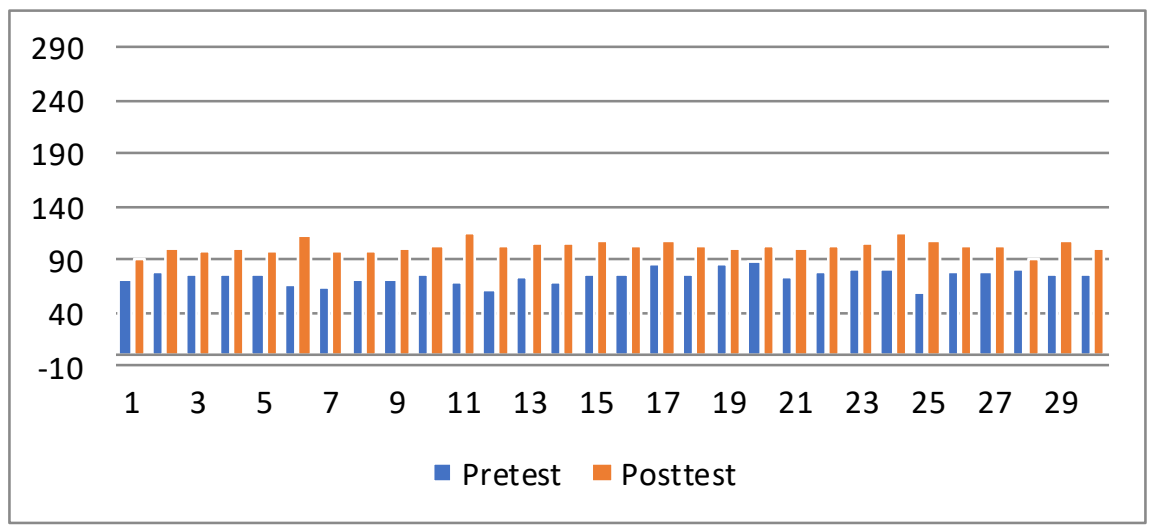

Gambar 1.Diagram Hasil Pretest dan Posttest Perencanaan Karier Siswa

Berdasarkan Gambar 1 dapat diketahui bahwa terdapat perbedaan perencanaan karier siswa sebelum dan sesudah diberi perlakuan layanan informasi bermuatan pembelajaran kontekstual dengan materi karier John Holland. Sebanyak 33 orang siswa mengalami peningkatan terhadap perencanaan karier sesudah diberikan perlakuan.

\section{PENGUJIAN HIPOTESIS}

Untuk menguji hipotesis dalam penelitian ini digunakan uji t atau $t$ test bantuan program SPSS versi 17.00. Adapun hipotesis yang diajukan dalam penelitian ini adalah “terdapat perbedaan yang signifikan pada perencanaan karier 
siswa sebelum dan sesudah diberi layanan informasi bermuatan pembelajaran kontekstual dengan materi karier John Holland”. Pengujian hipotesis ini dilakukan dengan teknik Paired Samples t-test. Untuk menganalisis hasil penelitian, peneliti menggunakan bantuan program SPSS versi 17.00. Hasil perhitungan untuk hipotesis dapat dilihat pada tabel berikut ini.

Tabel 8. Hasil Analisis Paired Sample t-test Perbedaan Perencanaan Karier Siswa pada Pretest dan Posttest

\begin{tabular}{|c|c|c|c|c|c|c|c|c|}
\hline & \multicolumn{5}{|c|}{ Paired Differences } & \multirow{3}{*}{$\mathrm{t}$} & \multirow{3}{*}{$\mathrm{df}$} & \multirow{3}{*}{$\begin{array}{l}\text { Sig. (2- } \\
\text { tailed) }\end{array}$} \\
\hline & \multirow[t]{2}{*}{ Mean } & \multirow{2}{*}{$\begin{array}{c}\text { Std. } \\
\text { Deviatio } \\
\text { n }\end{array}$} & \multirow{2}{*}{$\begin{array}{l}\text { Std. } \\
\text { Error } \\
\text { Mean }\end{array}$} & \multicolumn{2}{|c|}{$\begin{array}{l}\text { 95\% Confidence } \\
\text { Interval of the } \\
\text { Difference }\end{array}$} & & & \\
\hline & & & & Lower & Upper & & & \\
\hline $\begin{array}{ll}\text { Pair } 1 & \text { Posttes } \\
& t- \\
& \text { Pretest }\end{array}$ & 27.394 & 9.199 & 1.601 & 24.132 & 30.656 & 17.107 & 32 & .000 \\
\hline
\end{tabular}

Berdasarkan Tabel 8, terlihat perbedaan rata-rata siswa sebelum dan sesudah diberi perlakuan yaitu sebesar 27.4 dengan Asymp. Sig.(2-tailed) sebesar 0.000. Hipotesis diterima apabila $P$-value lebih kecil dari taraf signifikansi 0.05. Dari hasil perhitungan tersebut diperoleh nilai $P$-value lebih kecil dari taraf signifikansi $0.05(0.000<0.05)$. Dengan demikian, hipotesis pada penelitian ini dapat diterima, di mana terdapat perbedaan yang signifikan pada perencanaan karier siswa sebelum dan sesudah diberi layanan informasi bermuatan pembelajaran kontekstual dengan materi karier John Holland.

\section{PEMBAHASAN}

Berdasarkan pengujian hipotesis dapat disimpulkan bahwa terdapat perbedaan yang signifikan pada perencanaan karier siswa sebelum dan sesudah diberi layanan informasi bermuatan pembelajaran kontekstual dengan materi karier John Holland. Hal ini dapat terlihat dari nilai P-value yang lebih kecil dari taraf signifikansi $0.05(0.00<0.05)$. 
Penggunaan Materi Teori....(Ramtia Darma Putri)

Pembelajaran dikatakan menggunakan pendekatan kontekstual jika materi pembelajaran tidak hanya tekstual melainkan dikaitkan dengan penerapannya dalam kehidupan sehari-hari peserta didik di lingkungan keluarga, masyarakat, alam sekitar, dan dunia kerja, dengan melibatkan ketujuh komponen utama tersebut, sehinggga pembelajaran menjadi bermakna bagi peserta didik. Model pembelajaran apa saja yang memenuhi persyaratan tersebut dapat dikatakan menggunakan pendekatan kontekstual. Pembelajaran kontekstual memanfaatkan berbagai sumber dan media pembelajaran yang ada di lingkungan sekitar, sehingga tidak memerlukan biaya yang besar dan media khusus (Jumadi, 2003).

Pemberian layanan informasi bermuatan pembelajaran kontekstual dengan materi karier John Holland terbukti dapat meningkatkan perencanaan karier siswa. Layanan informasi bermuatan pembelajaran kontekstual dengan materi karier John Holland dilakukan dengan membagi kelas menjadi beberapa kelompok untuk membahas materi yang telah ditentukan. Teori bimbingan karier John Holland mencoba untuk memaparkan bagaimana siswa atau individu memilih karier yang sesuai dengan tipe, sifat, dan karakteristik psikologis (kepribadian) dengan model lingkungan yang mencakup lingkungan: realistis; intelektual; sosial; konvensional; usaha; dan artistik (Afandi, 2011). Selain itu, pemberian tugas juga diberikan untuk dipecahkan secara berkelompok pula.

Layanan informasi dengan pendekatan contextual teaching and learning sebagai salah satu pilihan strategi belajar yang membuat siswa aktif, sehingga siswa dapat membangun pengetahuan di dalam benaknya sendiri (Putri, Neviyarni \& Irianto, 2015). Lebih lanjut, Putri \& Ramadhani (2017) menjelaskan layanan informasi yang diberikan melalui pembelajaran kontekstual secara konsep mendukung kegiatan belajar siswa aktif, menemukan dan menciptakan makna melalui pengalaman serta pengetahuan yang sudah ada sebelumnya untuk membangun pengetahuan yang baru.

Keberhasilan layanan informasi bermuatan pembelajaran kontekstual dengan materi karier John Holland ditunjukkan dengan adanya peningkatan hasil 
rata-rata skor arah perencanaan karier siswa dari 75.5 menjadi 103. Adanya peningkatan rata-rata skor perencanaan karier siswa diduga diperoleh dari kebermaknaan proses pembelajaran yang dialami oleh siswa. Proses pembelajaran yang dialami oleh siswa tersebut seperti pengungkapan pengetahuan awal siswa mengenai materi, menemukan, kegiatan bertanya, adanya masyarakat belajar, siswa sebagai model pembelajaran, adanya refleksi terhadap materi,dan adanya penilaian autentik (Putri, 2015).

\section{KESIMPULAN DAN SARAN}

Berdasarkan hasil penelitian yang diperoleh, dan setelah melakukan pengujian secara statistik, serta pengujian hipotesis, maka dapat disimpulkan bahwa perencanaan karier siswa dapat ditingkatkan melalui pemberian layanan informasi bermuatan pembelajaran kontekstual dengan materi karier John Holland.

Sehubungan dengan hasil penelitian yang telah diperoleh pada penelitian ini, maka dapat disimpulkan beberapa saran yaitu sebagai berikut.

1. Bagi Siswa

Bagi siswa yang mengalami permasalahan dalam perencanaan karier untuk mengikuti layanan informasi dengan baik agar siswa dapat memahami keadaan diri beserta lingkungannya untuk mencapai karier.

2. Bagi Guru BK atau Konselor

Bagi Guru BK atau Konselor untuk menyusun program, khususnya format klasikal dalam meningkatkan perencanaan karier siswa. Guru BK atau Konselor dapat mengadakan layanan secara klasikal terjadwal terutama kepada siswa kelas lain yang belum mendapatkan layanan tersebut. 
Penggunaan Materi Teori....(Ramtia Darma Putri)

\section{DAFTAR PUSTAKA}

Afandi, M. 2011.” Tipe Kepribadian dan Model Lingkungan dalam Perspektif Bimbingan Karier John Holland”. Jurnal Sosial Budaya, Vol. 8 No 01 Januari-Juni 2011.

Jumadi, 2003. "Pembelajaran Kontekstual dan Implementasinya”. Makalah, (Online), http://staff.uny.ac.id/system/files/pengabdian/jumadi-mpd-dr/ pembelajaran-kontekstual.pdf, diakses 19 November 2017).

Nesidatu, A. 2015. "Pengangguran Picu Kriminalitas di Palembang”. (Online). (www.tabloidpodium.com/berita--pengangguran-picu-krimnalitas-dipalembang.html, diakses 14 Maret 2017)

Putri, R.D., Neviyarni \& Irianto, A. 2015. "Efektivitas Layanan Informasi dengan Pendekatan Contextual Teaching and Learning dalam Meningkatkan Arah Perencanaan Karier Siswa SMK”. Jurnal Konselor, Volume 4 Number 3 September 2015.

Putri, R.D., \& Ramadhani, E. 2017. "Implementasi Pembelajaran Kontekstual dalam Bimbingan dan Konseling”. Prosidin Dosen Universitas PGRI Palembang, Edisi 18 Tahun 2018.

Taniredja, T., Faridli, E. M., \& Harmianti, S. 2013. Model-model Pembelajaran Inovatif dan Efektif. Bandung: Alfabeta.

Yusuf, A.M. 2002. Kiat Sukses dalam Karier. Padang: Ghalia Indonesia. 